\title{
THE IMPORTANCE OF NATURAL HISTORY STUDIES FOR A BETTER COMPREHENSION OF ANIMAL-PLANT INTERACTION NETWORKS
}

\author{
A IMPORTÂNCIA DE ESTUDOS SOBRE HISTÓRIA NATURAL PARA A MELHOR \\ COMPREENSÃO DAS REDES DE INTERAÇÕES ANIMAL-PLANTA
}

\author{
Kleber DEL-CLARO'; ${ }^{1}$ Vanessa STEFANI'; Denise LANGE'; Andrea Andrade VILELA ${ }^{2}$; \\ Larissa NAHAS ${ }^{2}$; Mariana VELASQUES ${ }^{2}$; Helena Maura TOREZAN-SILINGARDI ${ }^{1}$ \\ 1. Biólogo(a), Doutor(a), Universidade Federal de Uberlândia, UFU, Uberlândia, MG, Brasil. delclaro@ufu.br; 2. Bióloga, doutoranda \\ no curso de pós-graduação em Ecologia e Conservação de Recursos Naturais - UFU, Uberlândia, MG, Brasil.
}

\begin{abstract}
The central tendency in ecological studies to explain variations in the outcomes of biotic interactions is to suppose that the majority of meaningful functional diversity occurs at the species level. However, individuals are rarely identical and behavioral ecology shows that consistent individual differences alter the roles that individuals play within populations and possibly communities, but the intraspecific variation is commonly ignored in studies of species interactions. Here, throughout examples of field work studies, we discuss that the knowledge of individual aspects (including genetic variation) and natural history are basic tools and fundamental to a real and whole comprehension of species interaction networks in qualitative and quantitative terms.
\end{abstract}

KEYWORDS: Ant. Biodiversity. Cerrado. Fructification. Life history. Phenology.

\section{INTRODUCTION}

The success of life on Earth is directly associated to the success of biotic interactions. Everywhere, in the air, water, ground, over or inside organisms, whether big or small, biotic interactions are present. The richness of biotic interactions ("interaction biodiversity", sensu THOMPSON, 1997) has been pointed out as the main force responsible for the biodiversity that maintain viable communities. In a more recent and realistic perspective biodiversity should be viewed and evaluated also in ways that embrace the extreme richness inherent in plant animal interactions, including not only trophic relationships, but also aspects of life histories, biology and behavior of related species (PRICE, 2002; DEL-CLARO, 2004). Despite ubiquitous the outcomes of each interaction vary depending on physical and biotic changes in the environment. Thus, there is no mutualism, for example, that will be ever and unconditionally a mutualism. Same parasitic or predatory relationships may suffer changes more slowly or quickly over evolutionary time that can drive the results of the interaction in a different direction (see DELCLARO; TOREZAN-SILINGARDI，2012, for a review). The central tendency in ecological studies to explain these variations is to suppose that the majority of meaningful functional diversity occurs at the level of the species and intraspecific variation is commonly ignored (PRUITT; FERRARI, 2011). Nevertheless, individuals are rarely identical and behavioral ecology, for example, has showed that consistent individual differences in personality and/or temperament may alter the roles that individuals play within populations and possibly communities (e.g. SIH et al., 2004, 2012; PRUITT; FERRARI, 2011). Thus, the knowledge of individual aspects (including genetic variation) and natural history are fundamental to the study of biodiversity.

\section{DEVELOPMENT}

Discussing the importance of natural history studies on animal and plant interactions

Among all group of interactions, those between animals and plants have been pointed out as the main interactions responsible for the functioning and maintenance of trophic chains in all ecosystems and for the patterns and process that structure biodiversity on Earth (THOMPSON, 1994, 2005; DEL-CLARO; TOREZAN-SILINGARDI, 2009, 2012). In these systems, changes in the outcomes of interactions between seasons and/or years are common and represent a clear example of how important the study of natural history of related species to the real understanding of interactions is. For example, although greatly recognized as relevant, plant phenological variations are rarely considered in studies of plant-animal network interactions.

Recently Torezan-Silingardi (2007) and Vilela (2010) showed the relevance of phenological events to herbivores networks. Studying a group of Malpighiaceae species in the tropical savanna these 
authors showed that pollinators, herbivores and their predators, all may move on among host plants over the year. The change between plant species is influenced by which host species is offering itself as resource at that time (i.e. young leaves, blossoms, petals). In some cases, herbivores (more than 300 species), including florivores that can be generalists or specialists, were associated with one to six different plant species. Both authors showed that the sequential resprouting and flowering of Malpighiaceae species in the Cerrados provided food and shelter that sustain a great guild of herbivores in a very seasonal environment. TorezanSilingardi (2007) also showed that several species of endophytic beetles (mainly Curculionidae, Figure 1a) that move on from one host plant to another, following the hosts plants species sequential resprouting and flowering, brings its predators together and influencing the fructification (TOREZAN-SILINGARDI, 2011a, Figure 1a). It emphasizes the importance of links between the natural history of related species to the comprehension of connections in trophic chains (TOREZAN-SILINGARDI, 2011b).

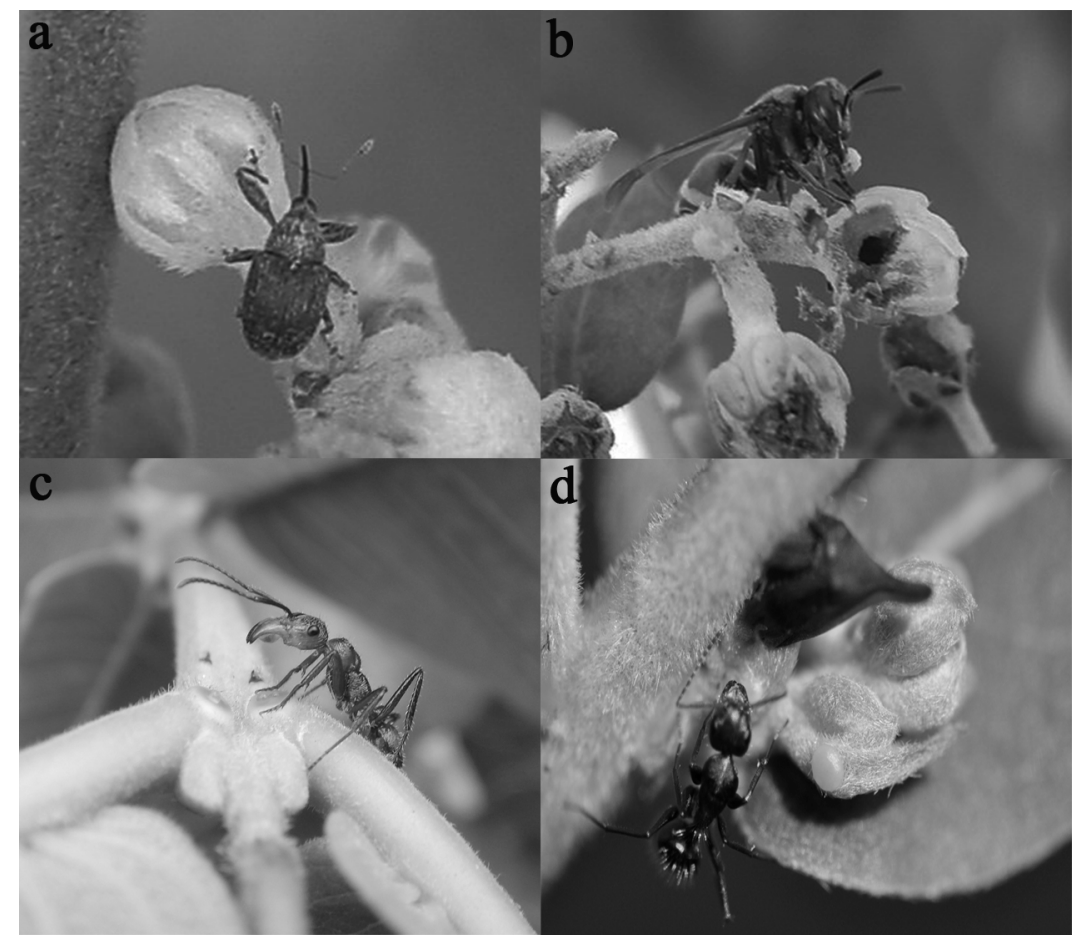

Figure 1. Herbivores (a - Curculionidae beetle - Antonomus sp.) can move on among host plants over time, attracting predators like wasps (b - Brachygastra lecheguana (Latreille, 1824) preying an endophytic beetle larva). Plants can offer resources, like extrafloral nectar (c - Ectatomma tuberculatum (Olivier, 1792) visiting EFNs in Qualea multiflora) or host trophobiont herbivores, like membracids (d - Camponotus crassus Mayr, 1862 tending a membracid in an EFN bearing Malpighiaceae) that also feed and attract ants that can prey on or chase herbivores.

\section{Ant-plant-herbivore interactions}

Literature on ant-plant-herbivore interactions is full of examples in which ecological studies overlooked the importance of individual variation and natural history studies. Myrmecophilous plants may offer as resources to ants: a) shelter (domatia and dead or hollow trunks) where they can build nests (RICO-GRAY; OLIVEIRA, 2007; SANTOS; DEL-CLARO , 2009); and b) food, mainly extrafloral nectar (LACH et al., 2009; BYK; DEL-CLARO, 2011, Figure 1c) and/or hemipteran (DEL-CLARO, 2004, Figure 1d) or lepidopteran exudates (FIEDLER; SAAM, 1995). In retribution, ants can benefit the plants mainly due to the removal of herbivores, reducing leaf are loss (KÖRNDORFER; DEL-CLARO, 2006) and increasing fruit set production (NASCIMENTO; DEL-CLARO, 2010). In the Brazilian tropical savanna, the membracid Guayaquila xiphias (Fabricius, 1803) (Hemiptera: Membracidae) has as host plant an Araliaceae, Schefflera vinosa (Cham and Schltdl.). In a series of publications (see DELCLARO; OLIVEIRA, 2000; OLIVEIRA et al., 2012, and citations therein) researchers showed that more than 21 different ant species tend the membracids providing them protection against natural enemies (mainly spiders and parasitoid wasps) increasing bug survivorship and 
reproduction. However, the benefits provided by ants vary over time depending on ant species behavior and the intensity and quality of enemy attack. In a similar system, Stefani and Del-Claro (2005) also showed that the benefit can be extended to the host plant, through the reduction of herbivory level, also dependent on the life history and behavior of associated ant species. Indeed, particular characteristics of ant species, like size (DELCLARO; MOUND, 1996), and/or behavioral aspects that vary intraspecifically, can interfere in the outcomes of these interactions. In the cited examples, the same interactions can have a mutualistic or parasitic character depending on a combination of associated natural histories. In both studies, authors needed one year of natural history studies in field to get to know the system and to elaborate a coherent protocol for experimental manipulations that answered their questions.

\section{Ecosystem Engineers}

The bottom-up forces in trophic chains, mainly herbivores, can alter plant architecture and influence on the whole chain that just one host plant sustains depending on species life histories and behavior. In natural environment some organisms can modify aspects of their niche making it more favorable to their existence. These transformations will affect other organisms and interactions during the life time and after the death of its creators. These animals are named "ecosystem engineers". Work to modify the environment is known for more than 150 years when Darwin firstly discussed the importance of worms in plant development (DARWIN, 1881). However, only recently the idea of ecosystem engineering was shaped, linking population ecology to ecosystem theory (JONES et al., 1994).

The first effect of ecosystem engineering is the modulation of available resources to other species, in a direct or indirect manner, which is caused by the modification produced by these animals in the physical state of biotic and abiotic materials (BERKE 2010). This interference in the habitat will influence the distribution and abundance of other organisms that use the same resource (LILL; MARQUIS 2007). In a recent research in the Brazilian Cerrado, Velasque (2011) showed the relevance of natural history and basic biology studies of ecosystem engineers to understand their impacts on the trophic chain they are involved in. During three years of field work, Velasque (2011) studied the interaction between the host plant Byrsonima intermedia A. Juss (Malpighiaceae) and its main herbivore, the larvae of the moth Cerconota achatina (Zeller, 1855) (Oecophoridae). The moth larvae is a concealed herbivore (Figure 2a) that attach host plant leaves, producing a shelter like a cigar, so called "cigar-moth shelter". In some cases more than 200 larvae are on the same plant and almost all stems of the plant present a cigar-moth shelter which greatly alters plant architecture (Figures 2b).

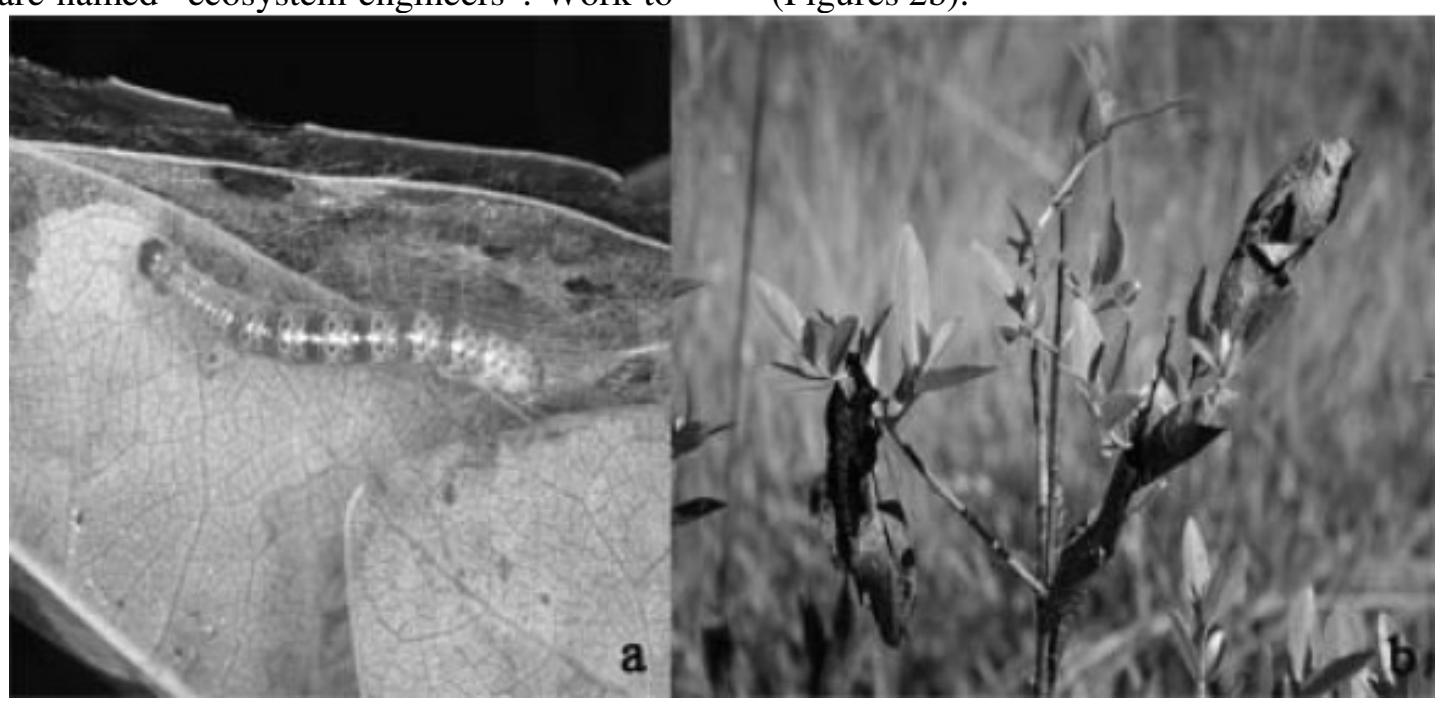

Figure 2. a) Moth larva, Cerconota achatina (Oecophoridae) in Byrsonima intermedia (Malpighiaceae). b) The moth larva is a concealed herbivore that attacks host plant leaves, which greatly alters plant architecture. Moth herbivore induces resprouting in the attacked plant stems.

Cigar-moth shelters can vary in size (length and thickness) depending on the position of steam (having small size in the apical meristem) and the number and behavior of larvae inside. The modification in plant architecture can directly benefit the larvae protecting them against adverse climatic conditions (excess of wind, sun, storms), natural enemies (i.e. ants; parasitoids; BÄCTHOLD 
et al., 2012) and also altering leaf chemistry, making it more palatable to the moth (see LILL; MARQUIS, 2007). In all phases the shelter can be used by a wide range of different animals including spiders, aphids and orthopterans, while larvae are still inside the cigar. When larvae leave the shelter, the structure now formed by dried leaves remains in the plant for several months and can be used by ants and same frogs and mice. The impact of this additional fauna on the host plants is unknown. However, the moth herbivore induced resprouting in the attacked plant stems (Figure 2b), and more infested plants produced more inflorescences and fruit. We suspect that specific plant individual characteristics (i.e. genetics, nutrition) will have a direct impact on resprouting and future flourishment. In a final analysis these impacts will also directly reflect on the next moth cycle. Furthermore, Velasque (2011) showed that the outcomes of this interaction vary strongly over time. Data like these can be obtained only with a consistent and permanent field work, taking into account the natural history of involved species and individual genetic analysis.

\section{Spider-plant interactions}

Turning our attention to the top-down forces in studies of multitrophic interactions it becomes still clearer how animal behavior and natural history of related species can produce strong variation in the results of interactions and in all levels of biodiversity. Spiders are among the most diverse animal taxa (more than 42.700 species according to PLATNICK, 2012) occurring in all terrestrial ecosystems (FOELIX, 2011). When foraging in vegetation spiders can positively interact with plants reducing herbivores abundance (ROMERO; VASCONCELLOS-NETO, 2004). Despite being known as an aggressive arthropod predator in some families (Anyphaenidae, Corinnidae, Clubionidae, Oxyopidae, Thomisidae and Salticidae) there are species that feed on plant resources, like nectar and pollen (SMITH; MOMMSEN, 1984; TAYLOR; FOSTER, 1996; TAYLOR; PFANNENSTIEL, 2008). Thomisidae is a family with several species that forage on flowers, and in a very interesting study of behavioral ecology and natural history. Pollard et al. (1995) showed that males of Misumenoides formosipes (Walckenaer, 1837) (Araneae: Thomisidae) also feed on floral nectar. The sugar obtained in nectar seems to be essential to the success of males to challenge rivals and to get access to females. Indeed, Jackson et al. (2001) showed that in laboratorial conditions more than 90 Salticidae species are able to feed on nectar, however, the histories behind each species and its interactions with plants are still not explored.

Colonial arachnids are in some circumstances treated as a superorganism due to the fact that grouped individuals share a strong genetic resemblance, have a common nest and feed and protect the colony in a cooperative manner (see DEL-CLARO; TIZO-PEDROSO, 2009; TIZOPEDROSO; DEL-CLARO, 2011 and citations therein). In Australia, Phryganoporus candidus (L. Koch, 1872) (Desidae) is a subsocial spider whose individuals attach the leaves and stems of Acacia ligulata A. Cunn. ex Benth, 1842 (Fabaceae) with silk to build its nest (WHITNEY, 2004). Field experiments showed that larger colonies of $P$. candidus occur significantly more in A. ligulata than in other plants. In this interaction spiders benefit from the plant not only preying on herbivores, but also feeding on extrafloral nectaries (EFNs). On the other hand, plants are also benefitted by a reduction in fruit herbivory (WHITNEY, 2004).

Recently, Nahas et al. (2012) showed that also in Brazilian Cerrados spiders use EFNs as a resource. Qualea multiflora Mart. (Vochysiaceae) is a common Cerrado tree that has EFNs in the basis of leaves attracting ants that protect the plant against herbivores action, reducing leaf area loss and increasing fruit set production (DEL-CLARO et al., 1996). However, spiders are also abundant in leaves and flowers of this plant, preying on arthropods and feeding on EFNs (Figure 3). Multiple predators often have effects on their common prey populations that cannot be predicted by summing the effects of each predator at a time. When predators forage on the same vegetation substrate, intraguild interactions might cause emergent outcomes for the plants on which the predators cooccur. In field conditions, Nahas et al. (2012) experimentally evaluated the effects of spiders and ants on herbivory and reproduction of $Q$. multiflora dividing the trees in four experimental groups, depending on the presence or absence of ants and spiders. Results showed that the presence of ants reduced the abundance and richness of spiders, but spiders did not affect the abundance and richness of ants. Only the removal of ants resulted in a statistically significant increase in the abundance of herbivores and herbivore richness. In addition, authors found a significant interaction effect of ants and spiders on herbivory, indicating an emergent multiple predator effect. This study highlights the importance of evaluating the effect of the predator fauna as a whole and not only one specific group on herbivory. 


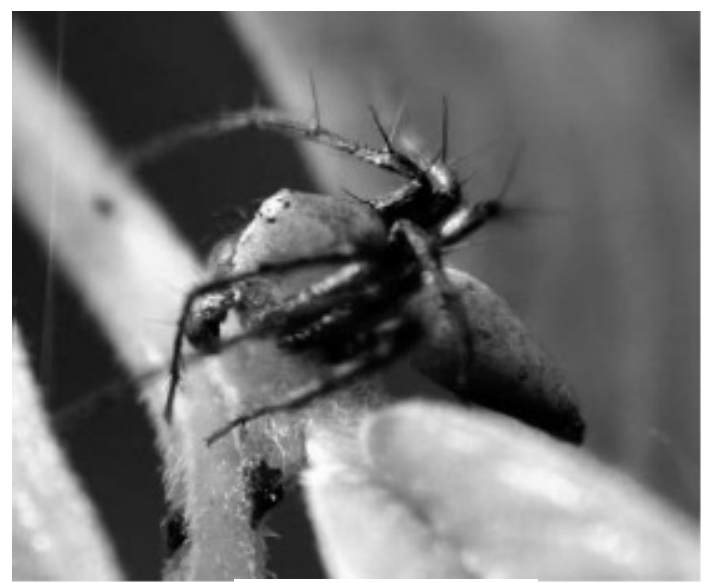

Figure 3. The spider Oxyopes macroscelides Mello-Leitao, 1929 (Oxyopidae) feeding on extrafloral nectar (EFN) of Qualea multiflora (Vochysiaceae).

However, spiders can also prejudice plantarthropod mutualistic relationships. Dukas and Morse (2003) showed that spiders can disturb pollinators that visit Asclepias shrubs (Apocynaceae). In the flowers of Leucanthemum vulgare Lamarck (Asteraceae), Suttle (2003) observed that the presence of spider Misumenops schligeri Schick, 1965 (Thomisidae) caused a significant reduction in pollinators visits (almost $40 \%$ ) and seed production. Thomisidae family has species with a complete different life history than Salticidae, Clubionidae and Oxyopidae. Remaining more time on flowers and inflorescences, Thomisidae will interact and prey on pollinators more commonly. While Salticidae, Clubionidae and Oxyopidae hunt over or under leaves and stems, rarely interacting with pollinators, but commonly preying herbivores. Again, studies of natural history of each species involved in a multitrophic relationship are essential for a true comprehension of the role that each species play in a particular scenario.

\section{Network of interactions}

The scale of possible interactions among organisms is astonishingly diverse (e.g. BRONSTEIN, 2009; DEL-CLARO; TOREZANSILINGARDI, 2012) and the analysis of these relationships by means of interaction networks has been considered fundamental for the comprehension of specialization patterns in plants and animals (BASCOMPTE; JORDANO, 2007; LEWINSOHN; CAGNOLO, 2012). Technically, the structure of species interaction networks can have five distinct patterns: extremely generalist, nested, compartmented, combined or in gradient (see LEWINSOHN et al., 2006; BASCOMPTE; JORDANO, 2007, for details). Studies suggest that differences in network structure are related to the type of effective interactions, i.e. the connections (JORDANO et al., 2003). Thus, mutualistic interactions like plants-pollinators and ants-EFNs bearing plants have a nested pattern (BASCOMPTE et al., 2003; GUIMARÃES et al., 2006, 2007), while nets of antagonistic relationships like plants and herbivores have a compartmented structure (LEIBOLD; MIKKELSON, 2002). Notwithstanding, some recent papers also found trophic chains (predator-prey interactions) with nested patterns (SELVA; FORTUNA, 2007; JOPPA et al., 2010; KONDOH et al., 2010) and compartmented plant-pollinator systems (DICKS et al., 2002). Possible answers to these differences can be related to ecological and evolutionary processes that affected species over time (LEWINSOHN et al., 2006), including the coevolutionary changes directly influenced by the different ecological roles that species can play in communities in distant geographic areas or evolutionary times (THOMPSON, 2005; BLÜTHGEN; KLEIN, 2011; BLÜTHGEN, 2012). In this sense, networks have been also used in studies of niche specializations and generalization of interacting species (BLÜTHGEN; KLEIN, 2011). There is no doubt, that studies of species interaction networks are considered as an important tool in the understanding of patterns and process that maintain biodiversity in natural communities.

However, despite the extensive use of interaction network studies in the last decade trying to explain patterns and process of diversity in natural communities, studies involving interactions among animals are still rare (see STOUFFER et al., 2012). Zoological aspects of animal-animal and same animal-plant interactions, like individual behavioral and genetic variations, are extensively ignored. Indeed, most published papers using network analysis to study interactions only present records of 
species connections performed in basic matrixes of connect or not connected links represented by 0 s and $1 \mathrm{~s}$ (presence and absence). There is a clear lack of data quantifying these interactions and showing the real nature of each interaction, which can only be provided by complementary natural history studies. For these reason, network analysis is often disconnected from community ecology and is a long away from its purposes (see BLÜTHGEN, 2010).

We summarize our arguments in favor of increasing and encouraging natural history studies in the last figure of this manuscript (Figure 4): ecological studies recognize that plant-animal populations are integrated in evolutionary old interactions that were selected over geographic and evolutionary time, establishing communities and maintaining patterns of diversity in the ecosystems. However, intraspecific variation (genetics), natural history and phenological development, despite being basic tools for the comprehension of outcomes as to plant-animal interactions in all trophic levels are commonly ignored. We expect that the examples shown here have been sufficient to support our strong suggestion that natural history studies are basic tools and fundamental for the whole comprehension of species interaction networks in qualitative and quantitative terms. In a qualitative manner, as only through knowing the character and possible variations in each link (interaction) inside each node of a network will we be able to know the role of each species in a multitrophic system. Quantitative, because variation in total observation frequencies (that which is rare in species interaction network studies) may explain network patterns on their own (see BLÜTHGEN, 2010, 2012).

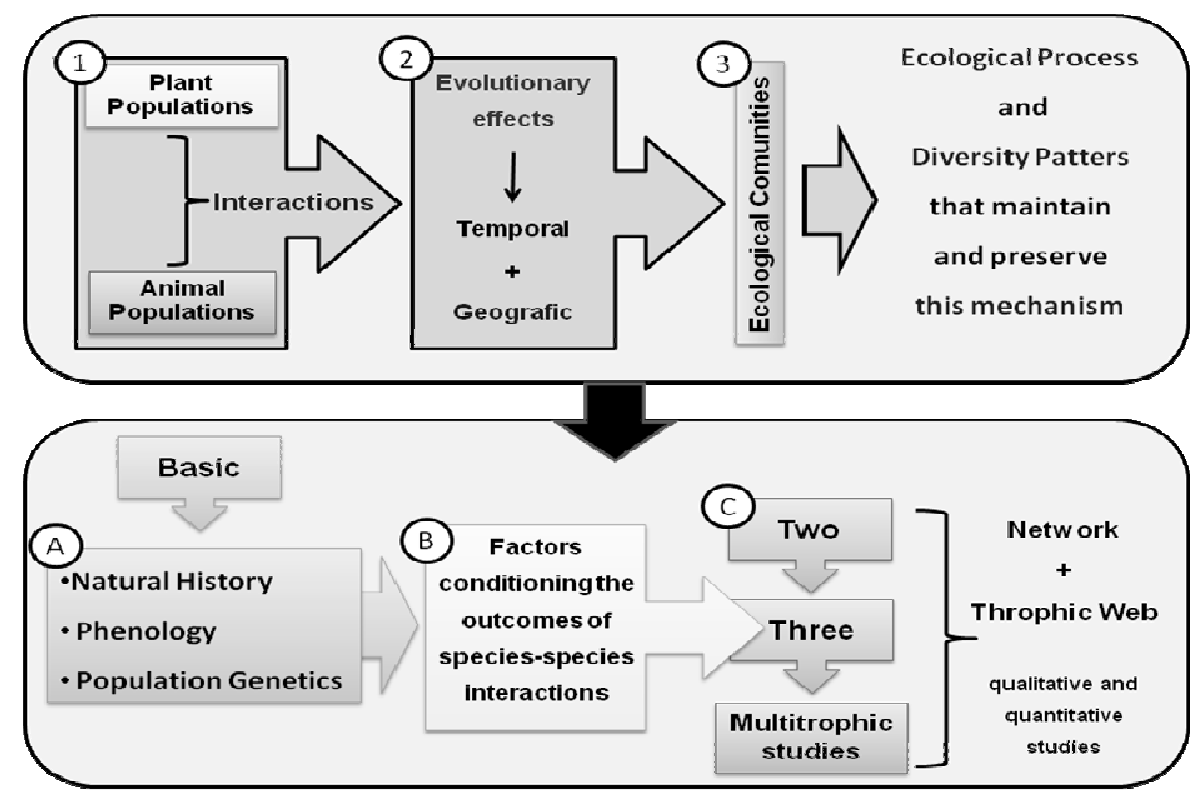

Figure 4. Ecological studies recognize that plant-animal populations are integrated in evolutionary old interactions (1) which have been selected over geographic and evolutionary time (2) establishing communities (3) and maintaining patterns of diversity in ecosystems. However, intraspecific variation (genetics), natural history and phenological development (A), despite being basic tools for the comprehension of outcomes in plant-animal interactions (B) in all trophic levels $(\mathrm{C})$, they are commonly ignored. We strongly suggest that these basic tools are fundamental to a more accurate comprehension of species interactions network in qualitative and quantitative terms.

\section{ACKNOWLEDGMENTS}

Authors thanks researches grants from Conselho Nacional de Desenvolvimento Científico e Tecnológico (CNPq) (K. Del-Claro: 476074/2008-8; 472046/2011-0; 301248/2009-5; D. Lange:

RESUMO: A tendência central em estudos ecológicos para explicar as variações nos resultados das interações bióticas é supor que a maioria da diversidade funcional significativa ocorre em nível de espécie. No entanto, indivíduos raramente são idênticos e a ecologia comportamental mostra que as diferenças individuais alteram os papéis que cada um
AT/500868/2010-7) and Coordenação de Aperfeiçoamento Pessoal de Nível Superior (CAPES) (K. Del-Claro and V. Stefani: 2651/2011; A. Vilela; M. Velasque; L. Nahas). We thanks one anonymous reviewer that improved text quality. 
desempenha dentro das populações e possivelmente dentro em comunidades; e essa variação intraespecífica é comumente ignorada em estudos de interações entre espécies. Aqui, por meio de exemplos de estudos de trabalho de campo, discutimos que o conhecimento de aspectos individuais (incluindo a variação genética) e história natural são ferramentas básicas e fundamentais para uma compreensão real e mais ampla sobre redes de interação entre espécies, em termos qualitativos e quantitativos.

PALAVRAS-CHAVE: Biodiversidade. Cerrado. Fenologia. Formigas. Frutificação. História de vida.

\section{REFERENCES}

BÄCHTOLD, A.; DEL-CLARO, K.; KAMINSKI, L. A.; FREITAS , A. V. L.; OLIVEIRA, P.S. Natural history of an ant-plant-butterfly interaction in a Neotropical Savanna. Journal of Natural History, London, v. 46, p. 943-954, 2012.

BASCOMPTE, J.; JORDANO, P.; MELIÁN, C. J.; OLESEN, J. M. The nested assembly of plant-animal mutualistic networks. Proceedings of the National Academy of Sciences, New York, v.100, p. 9383-9387, 2003.

BASCOMPTE, J.; JORDANO, P. Plant-animal mutualistic networks: the architecture of biodiversity. Annual Review of Ecology, Evolution and Systematics, Oxford, v. 38, p. 567-593, 2007.

BERKE, S. K. Functional Groups of Ecosystem Engineers: A Proposed Classification with Comments on Current Issues. Integrative and Comparative Biology, London v. 50, n. 2, p. 147-157, 2010

BLÜTHGEN, N. Why network analysis is often disconnected from community ecology: A critique and an ecologist's guide. Basic and Applied Ecology, Copenhagen, v.11, p. 185-195, 2010.

BLÜTHGEN, N.; KLEIN, A. M. Functional complementarity and specialization: Why biodiversity is important in plant-pollinator interactions. Basic and Applied Ecology, Copenhagen, v.12, n.4, p. 282-291, 2011.

BLÜTHGEN, N. Interações plantas-animais e a importância funcional da biodiversidade, In: Del-Claro, K.; Torezan-Silingardi, H. M. (Eds.). Ecologia das interações Animais-Plantas: Interações Planta-Animais e a importância funcional da biodiversidade. Rio de Janeiro: Technical Books Editora, 2012. p. 261-272.

BRONSTEIN, J. L. The evolution of facilitation and mutualism. Journal of Ecology, Oxford, v. 97, n.6, p. 1160-1170, 2009.

BYK, J.; DEL-CLARO, K. Ant-plant interaction in the Neotropical Savanna: direct beneficial effects of extrafloral nectar on ant colony fitness. Population Ecology, Sapporo, v. 53, n. 2, p. 327-332, 2011.

DARWIN, C. R. The formation of vegetable mould through the action of worms with observations on their habits. London: John Murray, 1881.138 p.

DEL-CLARO, K. Multitrophic Relationships, Conditional Mutualisms, and the Study of Interaction Biodiversity in Tropical Savannas. Neotropical Entomology, Curitiba, v. 33, n. 6, p. 665-672, 2004.

DEL-CLARO, K.; MOUND, L. A. Phenology and description of a new species of Liothrips (Thysanoptera: Phlaeotripidae) from Didymopanax in Brazilian Cerrado. Revista de Biología Tropical, San José, v. 44, n. 1, p. 193-197, 1996.

DEL-CLARO, K.; BERTO, V.; RÉU, W. Effect of herbivore deterrence by ants on the fruit set of an extrafloral nectary plant, Qualea multiflora (Vochysiaceae). Journal of Tropical Ecology, Oxford, v. 12, p. 887-892, 1996. 
DEL-CLARO, K.; OLIVEIRA, P. S. Conditional outcomes in a neotropical treehopper-ant association: temporal and species-specific effects. Oecologia, Munich, v. 124, p. 156-165, 2000.

DEL-CLARO, K.; TIZO-PEDROSO, E. Ecological and evolutionary pathways of social behavior in Pseudoscorpions (Arachnida: Pseudoscorpiones). Acta Ethologica, Lisboa, v. 12, p. 13-22, 2009.

DEL-CLARO, K.; TOREZAN-SILINGARDI, H. M. Insect-plant interactions: new pathways to a better comprehension of ecological communities in neotropical savannas. Neotropical Entomology, Curitiba, v. 38, p. $159-164,2009$.

DEL-CLARO, K.; TOREZAN-SILINGARDI, H. M. Ecologia das Interações Plantas-Animais: Uma Abordagem Ecológico-Evolutiva. Rio de Janeiro : Technical Books, 2012. 333 p.

DICKS, L. V.; CORBET, S. A.; PYWELL, R. F. Compartmentalization in plant-insect flower visitor webs. Journal of Animal Ecology, London, v. 71, p. 32-43, 2002.

DUKAS, R.; MORSE, D. H. Crab spiders affect flower visitation by bees. Oikos, Munich, v. 101, p. 157-163, 2003.

FIEDLER, K. L.; SAAM, C. Ants benefit from attending facultatively myrmecophilous Lycaenidae caterpillars: evidence from a survival study. Oecologia, Munich, v. 104, p. 316-322, 1995.

FOELIX, R. F. Biology of spiders. New York: Oxford: Oxford University Press, 2011. 428 p.

GUIMARÃES, P. R. JR.; RICO-GRAY, V.; REIS, S. F.; THOMPSON, J. N. Asymmetries in specialization in ant-plant mutualistic networks. Proceedings of the Royal Society B, London, v. 273, p. 2041-2047, 2006.

GUIMARÃES, P. R. JR.; RICO-GRAY, V.; OLIVEIRA, P. S.; IZZO, T. J.; REIS, S. F. DOS; THOMPSON, J. N. Interaction intimacy affects structure and coevolutionary dynamics in mutualistic networks. Current Biology, Chicago, v. 17, p. 1-7, 2007.

JACKSON, R. R.; POLLARD, S. D.; NELSON, X. J.; EDWARDS, G. B.; BARRION, A. T. Jumping spiders (Araneae: Salticidae) that feed on nectar. Journal of Zoology, London, v. 255, p. 25-29, 2001.

JONES, C. G.; LAWTON, J. H.; SHACHAK, M. Organisms as Ecosystem Engineers. Oikos, Munich, v. 69, n. 3, p. 373-386, 1994.

JOPPA, L. N.; SOLÉ, R.V.; SANDERSON, J.; PLIMM, S. L. On nestedness in ecological networks.

Evolutionary Ecology Research, London, v. 12, p. 35-46, 2010.

JORDANO, P.; BASCOMPTE, J.; OLESEN, J. M. Invariant properties in coevolutionary networks of plantanimal interactions. Ecology Letters, New York, v. 6, p. 69-81, 2003.

KONDOH, M.; KATO, S.; SAKATO, Y. Food webs are built up with nested subwebs. Ecology, New York, v. 91, p. 3123-3130, 2010.

KORNDÖRFER, A. P.; DEL-CLARO, K. Ant defense versus induced defense in Lafoensia pacari (Lythraceae), a myrmecophilous tree of the Brazilian Cerrado. Biotropica, East Anglia, v. 38, n. 6, p. 786-788, 2006.

LACH, L.; HOBBS, E. R.; MAJER, E. J. D. Herbivory-induced extrafloral nectar increases native and invasive ant worker survival. Population Ecology, Sapporo, v. 51, p. 237-243, 2009.

LEIBOLD, M. A.; MIKKELSON, G. M. Coherence, species turnover, and boundary clumping: elements of meta-community structure. Oikos, Munich, v. 97, n. 2, p. 237-250, 2002. 
LEWINSOHN, T. M.; PRADO, P. I.; JORDANO, P.; BASCOMPTE, J.; OLESEN, J. Structure in plant-animal interaction assemblages. Oikos, Munich, v. 113, p. 174-184, 2006.

LEWINSOHN, T. M.; CAGNOLO, L. Ecology Keystones in a Tangled Bank. Science, New Jersey, v. 335, p. 1449-1451, 2012.

LILL, J. T.; MARQUIS, R. Microhabitat manipulation: Ecosystem engineering by shelter building insects. In: CUDDINGTON, K. M. D.; BYERS, J. E.; HASTINGS, A.; WILSON, W. G. (Eds.). Ecosystem engineers: concepts, theory, and applications in ecology. San Diego: Elsevier Press, 2007. p. 107-138.

NAHAS, L.; GONZAGA, M. O.; DEL-CLARO, K. Emergent Impacts of Ant and Spider Interactions: Herbivory Reduction in a Tropical Savanna Tree. Biotropica, East Anglia, v. 44, p. 498-505, 2012

NASCIMENTO, E. A.; DEL-CLARO, K. Ant visitation to extrafloral nectaries decreases herbivory and increases fruit set in Chamaecrista debilis (Fabaceae) in a Neotropical savanna. Flora, Munich, v. 205, p. 754$756,2010$.

OLIVEIRA, P. S.; SENDOYA, S. F.; DEL-CLARO, K. Defesas bióticas contra herbívoros em plantas do Cerrado: Interações entre formigas, nectários extraflorais e insetos trofobiontes. In: DEL-CLARO, K.; TOREZAN-SILINGARDI, H. M. (Eds.). Ecologia das Interações Plantas-Animais: Uma Abordagem Ecológico-Evolutiva. Rio de Janeiro: Technical Books, 2012. p.155-168.

PLATNICK, N. I. The world spider catalog, version 12.0. American Museum of Natural History. New York, 2012. Disponível em: http://research.amnh.org/iz/spiders/catalog. Acesso em: 07-maio. 2012.

POLLARD, S. D.; BECK, M. W.; DODSON, G. N. Why do male crab spiders drink nectar? Animal Behavior, Chicago, v. 49, p. 1443-1448, 1995.

PRICE, P. W. Species interactions and the evolution of biodiversity, In: HERRERA, C. M.; PELLMYR, O. (Eds.). Plant-animal interactions: An evolutionary approach. Oxford: Blackwell Science, 2002. p. 3-25.

PRUITT, J. N.; FERRARI, M. C. O. Intraspecific trait variants determine the nature of interspecific interactions in a habitat-forming species. Ecology, New Jersey, v. 92, n. 10, p. 1902-1908, 2011.

RICO-GRAY, V.; OLIVEIRA, P. S. The ecology and evolution of ant-plant interactions. Chicago: The University of Chicago Press, 2007. 331 p.

ROMERO, G. Q.; VASCONCELLOS-NETO, J. Foraging by the flower-dwelling spider, Misumenops argenteus (Thomisidae), at high prey density sites. Journal of Natural History, London, v. 38, p. 1287-1296, 2004.

SANTOS, J. C.; DEL-CLARO, K. Ecology and behaviour of the weaver ant Camponotus (Myrmobrachys) senex. Journal of Natural History, London, v. 43, p. 1423-1435, 2009.

SELVA, N.; FORTUNA, M. A. The nested structure of a scavenger community. Proceeding of the Royal Society B: Biological Sciences, London, v. 274, p. 1101-1108, 2007.

SIH, A.; BELL, A.; JOHNSON, J. C. Behavioral syndromes: an ecological and evolutionary overview. Trends in Ecology and Evolution, Genebra, v. 19, p. 372-378, 2004.

SIH, A.; JULIEN, C.; FOGARTY, E. M.; PRUIT, J. Ecological implications of behavioural syndromes.

Ecology Letters, New York, v. 15, n. 3, p. 278-289, 2012.

SMITH, R. R.; MOMMSEN, T. P. Pollen feeding in an orb-weaving spider. Science, New York, v. 226, p. 133-1333, 1984. 
STEFANI, V. S. M.; DEL-CLARO, K. The outcomes of an ant-threehopper association on Solanum lycocarpum St. Hil: increased membracid fecundity and reduced damage by chewing herbivores. Neotropical Entomology, Curitiba, v. 34, n. 6, p. 881-887, 2005.

STOUFFER, D. B.; PARDO, M. S.; SIRER, M. I.; Bascompte, J. Evolutionary Conservation of Species' Roles in Food Webs. Science, New York, v. 335, p. 1489-1492, 2012.

SUTTLE, K. B. Pollinators as mediators of top-down effects on plants. Ecology Letters, New York, v. 6, p. 688-694, 2003.

TAYLOR, R. M.; FOSTER, W. A. Spider nectarivory. American Entomologist, Chicago, v. 42, p. 82-86, 1996.

TAYLOR, R. M.; PFANNENSTIEL, R. S. Nectar feeding by wandering spiders on cotton plants. Environmental Entomology, Oxford, v. 37, p. 996-1002, 2008.

THOMPSON, J. N. The Coevolutionary Process. Chicago: University of Chicago Press, 1994. 376 p.

THOMPSON, J. N. Conserving interaction biodiversity. In: PICKETT S. T. A.; OSTFELD, R. S.; SHACHAK, M.; LIKENS, G. E. (Eds.). The ecological basis of conservation: Heterogeneity, ecosystems, and biodiversity. New York: Chapman \& Hall, 1997. p. 285-293

THOMPSON, J. N. The Geographic Mosaic of Coevolution. Chicago: University of Chicago Press, 2005. $400 \mathrm{p}$.

TIZO-PEDROSO, E.; DEL-CLARO, K. Is there division of labor in cooperative Pseudoscorpions? An Analysis of the Behavioral Repertoire of a Tropical Species. Ethology, London, v. 117, p. 498-507, 2011.

TOREZAN-SILINGARDI, H. M. A influência dos herbívoros florais, dos polinizadores e das características fenológicas sobre a frutificação de espécies da família Malpighiaceae em um Cerrado de Minas Gerais. 2007. 230 f. Tese Ph. D. Thesis (Doutorado em Entomologia)- Curso de Pós Graduação em Entomologia, Universidade de São Paulo.

TOREZAN-SILINGARDI, H. M. Predatory behavior of Pachodynerus brevithorax (Hymenoptera: Vespidae, Eumeninae) on endophytic herbivore beetles in the Brazilian Tropical Savanna. Sociobiology, Austin, v. 57, p. 181-189, 2011 a.

TOREZAN-SILINGARDI, H. M. Uma introdução ao estudo dos herbívoros florais, In: TOREZANSILINGARDI, H. M.; STEFANI, V. (Orgs.). Etologia 2011: temas atuais em Etologia e Anais do XXIX Encontro Anual de Etologia. Uberlândia: UFU, 2011b. p. 35-42.

VELASQUE, M. Sazonalidade e herbivoria e sua influencia em Byrsonima intermedia. 2011. $54 \mathrm{f}$. Monografia (Graduação em Ciências Biológicas), Curso de Graduação em Ciências Biológicas, Universidade Federal de Uberlândia, 2011.

VILELA, A. A. Interações ecológicas em Malpighiaceae no Cerrado: compartilhamento de guildas de herbívoros e variações nos resultados da interação formiga-planta. 2010. 98 f. Dissertação (Mestrado em Ecologia e Conservação de recursos Naturais), Curso de Pós-Graduação em Ecologia e Conservação de recursos Naturais, Universidade Federal Uberlândia, 2010.

WHITNEY, K. D. Experimental evidence that both parties benefit in a facultative plant-spider mutualism. Ecology, New York, v. 85, p. 1642-1650, 2004. 